\title{
Refusal of Ratification of Omnibus Law According to Sociology of Law
}

\author{
Yudita Nuriyah An-Nisa ${ }^{1, *}$ Agus Machfud Fauzi ${ }^{2}$
}

\author{
${ }^{1,2}$ Universitas Negeri Surabaya \\ ${ }^{*}$ Corresponding author. Email: yudita.19028@mhs.unesa.ac.id
}

\begin{abstract}
This article describes the passing of the omnibus law of the work copyright bill. The purpose of this article is to determine the effect of the ratification of the omnibus law. The process of ratifying the law is carried out at night when the position of the majority of citizens is relaxing. Besides, the state of the nation is being shocked by the entry of the coronavirus into Indonesia. The research uses qualitative methods with literature study, which explains by raising a phenomenon that occurs in society. The ratification of this omnibus law makes most people disapprove of the new law passed by the DPR. By bringing influence and causing rejection from the Indonesian people, especially workers and students. Demonstrations are a form of rejection that is usually carried out by Indonesian people. The author examines the ratification of the omnibus law or the Job Creation Bill that occurred in the Bangkalan area, Madura. Data collection techniques were carried out using documentation and literature from the news. Judging from the various places that held demonstrations, the author's focus here is specifically in the Bangkalan area by seeing what the reaction and the people there look like.
\end{abstract}

Keywords: Job creation bill, demonstration, society.

\section{INTRODUCTION}

Demonstrations against the Indonesian House of Representatives (DPR) took place again in Indonesia on October 6-8 2020. Indonesia is currently still said to be a country that is considered to be highly affected by COVID-19, but this situation did not dampen the intentions of the demonstrators. Demonstrations are a form of rejection due to ratification which is considered inappropriate for Indonesian society. Demonstrations that occur in Indonesia are usually carried out by students where they voice the voice of the people by demonstrating or a form of rejection. The demonstration is currently being carried out by workers and students who reject the ratification of the omnibus law bill. This demonstration event seems to remind us of previous demonstrations which were also addressed to the Indonesian House of Representatives. Previously regarding the revision of the Criminal Code Law and the KPK Law on September 19, 2019.

At this time the ratification of the omnibus law bill is considered inappropriate and not suitable for the Indonesian people, especially workers or laborers. The ratification of the bill was carried out during the 7 th plenary session of the 2020-2021 trial period at the Parliament Complex, Senayan, Jakarta. The process coincided with the accelerated closing of the first trial period. The ratification of the omnibus law bill raises two important points to be ratified, namely the Ciptaker Bill and the taxation bill. One of the draft laws on the omnibus law, namely the work copyright law, can get a lot of rejection from the public and is considered too important for investors. The abundance of natural wealth owned by the Indonesian state is an attraction for other nations. Such as mining products, spices, oil sources, and other sources. This has invited many foreign companies and investors to invest in Indonesia. It seems that this natural potential still makes Indonesia a developing country. The ratification of this bill is a draft from the president which is then submitted to the government which will later be ratified by the DPR.

The ratification of the omnibus law took place on Monday, October 5, 2020. With the hammer knocking process carried out at night, when most people were resting. How is it possible that the ratification of the bill was carried out without the consent of the Indonesian people, from here the whole community took action against it the next day after its ratification? However, 
people who hold demonstrations are encouraged to continue to wear masks to prevent the spread of covid19. The refusal action was carried out by workers, students, the community, and even students. Most of the workers went on strike for 3 days because they were about to stage a demonstration. Demonstrations were carried out in various parts of Indonesia simultaneously and simultaneously. Simultaneous demonstrations are planned by BEM SI (Student Executive Board throughout Indonesia) which will be held on thursday, october 8, $2020^{[2]}$

The relationship between the dpr and the community is indeed very closely related because the dpr itself is a representative of the people who should indeed hear the aspirations of the people. Based on the description above, it explains that there is a connection with the ratification of the omnibus law bill with the community, especially workers and students. Researchers are interested in knowing and understanding how the people of bangkalan, madura respond to the ratification of the omnibus bill on copyright.

\section{METHODS}

The research method used is qualitative research and words as study material by describing the results of the analysis that have been designed and obtained by utilizing various scientific methods ${ }^{[11]}$.

The collection method used is a literature study. A literature study is done by linking journals, books, and news related to the problems that occur. The research subjects were people who took part in the demonstration at the Bangkalan DPRD and news about the omnibus law demonstration that occurred on Tuesday, October 13, 2020, on Instagram "wecarebangkalanmadura". The reason for choosing the media is because the sources are easy to obtain, the news that is trending will be reported by social media. Each breaking news of the omnibus law demonstration at the Bangkalan DPRD is as follows:

Table 1. Breaking News Demonstration of Omnibus Law in Bangkalan DPRD

\begin{tabular}{l}
\hline News Site \\
\hline www.koranmadura.com \\
\hline Instagram: wecarebangkalanmadura
\end{tabular}

This research will be discussed following the sociology of law. By linking the problems that occur in society with the existence of legal sociology. Data analysis was carried out in qualitative research by collecting data first. then the process of presenting the data and continued with data reduction. The last analysis process is concluded ${ }^{[14]}$.

\section{RESULTS AND DISCUSSION}

\subsection{Definition of Omnibus Law}

According to ${ }^{[7]}$ the omnibus law is one law that can revise dozens of laws at once. The purpose of the ratification of the omnibus law is to summarize and finalize several laws into one. Previously, the term omnibus law was used in President Joko Widodo's speech during the second presidential inauguration process.

The draft law (RUU) is made to simplify and streamline regulations so that they are right on target. The concept is making the omnibus law is also related to the economic sector in the field of government work $^{[10]}$. President Jokowi will take advantage of this crisis momentum bypassing the omnibus law. This was done to create a door that was as big as possible for investors. The ratification of the omnibus law by the DPR RI is expected to be able to build the economy of the Indonesian people, especially in doing business and doing business.

From the ratification of a new law with the aims and objectives made in such a way by the government. It is very unlikely that there will be a form of rejection from the community unless there is disagreement about the content or rules of the law. According to ${ }^{[13]}$ there are five regulations in the omnibus law on job creation that are deemed not in favor of workers, namely:

1. The threatened loss of the city or district minimum wage

One of the reasons for this refusal was the threat of losing the minimum wage for workers residing in cities ordistricts. Because this has been stated in the draft bill article $88 \mathrm{C}$, it reads that the minimum wage has been set by the governor as a safety net.

2. Lack of severance pay for layoffs

According to Ida Fauziyah, the minister of manpower explained that the changes to the severance pay rules were revised because the previous labor laws were not optimal in their application. In addition, some entrepreneurs are unable to provide severance pay. 
3. Menstrual leave removed

Article 93 letter a explains that the permission for the first day of menstruation has been suspended. In addition, in letter $\mathrm{b}$, the omnibus law also removes permits related to marrying, getting married, baptizing their children, giving birth even if one of their familymembers dies.

4. It's not clear when it comes to outsourcing

The omnibus law removes two articles related to outsourcing. The article is as follows:

Article 64 reads, the delivery of part of the implementation of workers can be carried out between companies with a written service or labor agreement.

Article 65 reads, the delivery of part of the implementation of workers can be carried out between companies in the presence of a written contractingagreement.

\section{Contracts for workers can be for life}

The abolition of Article 59 of Law no. 13 of 2003 concerning work contracts that can only be carried out for a maximum of 2 years. However, this article has been removed and gives freedom to labor contracts that can last for life.

Of the five regulations that are considered incompatible with the workers, this creates a form of rejection from the workers. At the beginning of the submission of files by the government, precisely in February, it received the attention of various workers or laborers. Coupled with the ratification by the Indonesian House of Representatives on Monday, October 5, 2020, it reaped various forms of rejection from the community, especially workers or laborers with student support.

\subsection{Sociology of Law}

Sociology of law is one of the sub-disciplines of sociology that examines behavioral patterns in society ${ }^{[6]}$. Sociology of law can be seen as a legal instrument to examine its object as a process of law implementation. Sociology of law can also be used as an instrument to examine legal decisions ${ }^{[5]}$. According to Soerjono Soekanto, the sociology of law is analytically and empirically studying the reciprocal relationship between law and social phenomena ${ }^{[4]}$.

According to J. Hall, sociology of law theoretically contains generalizations about societal phenomena, as far as the substance, application, and consequences of a rule of law are concerned ${ }^{[15]}$. According to CMJ Schyut, legal sociology is tasked with revealing the background of the occurrence of inequality between community regulations and the reality of society.

The function of the study of the sociology of law is to inform about the social context associated with the law. Sociology of law is useful for providing skills for understanding law in a social context. The use of the concepts of the sociology of law can provide the ability to analyze the effectiveness of law in society. Sociology of law can also provide the ability to evaluate the effectiveness of law in society ${ }^{[6]}$.

The problem, in this case, is seen in the perspective of the sociology of law, which explains the problems that occur in a society that is closely related to law. A little previous explanation proves that the ratification of the omnibus law is one of the problems that can be investigated in the sociology of law.

\subsection{Demonstration}

According to the KBBI, a demonstration is a statement of disagreement that is carried out in a crowd or better known as a demonstration. According to lecturersosiologi.com demonstrations are actions that are carried out en masse to change government policies that are considered incompatible with it ${ }^{[5]}$.

Demonstrations are also often interpreted as freedom of opinion, but this form of expression of opinion is carried out to oppose a policy that is considered politically inappropriate. A demonstration activity is regulated by law. If later in the demonstration process takes place there is news that displays news about the arrest of demonstrators, then it happens because there are demonstrators who violate the law.

Several supporting factors can lead to demonstrations, namely:

\section{Media and Press}

The presence of the media and the press captures the moment about the ongoing demonstration activities. The role of the media and the press here is as news seekers and will cover events that occur in various places. Then it will be disseminated to television broadcasts, online news, and print media.

\section{Points or issues}

Demonstrations must be motivated by certain points or problems, which of course trigger an attitude of protest or rejection from a group, organization, worker, or student. Problems that often lead to demonstrations are more related 
to common interests, social justice, and human rights.

\section{Civil society}

The existence of the civilian side has a double meaning. First, the presence of civilians will lead to opinions that will be expressed by the demonstrators. This means that the civilian side has one goal with the demonstrators, namely to change the policies made by the government. Second, the presence of civilians sometimes aims to secure the location from anarchic demonstrations. This means that here the civilian side does not allow the demonstrators to make the location chaotic.

\section{Supporter}

The existence of rulers can be threatened and suppressed if demonstrations are supported by three important elements, namely, network support, military support, and financial support [3].

The following is a form of rejection of the omnibus law ratification by the people of Bangkalan, Madura. Narratives and news sourced from the Madura newspaper and Instagram accounts are the focus of research related to the sociology of law.

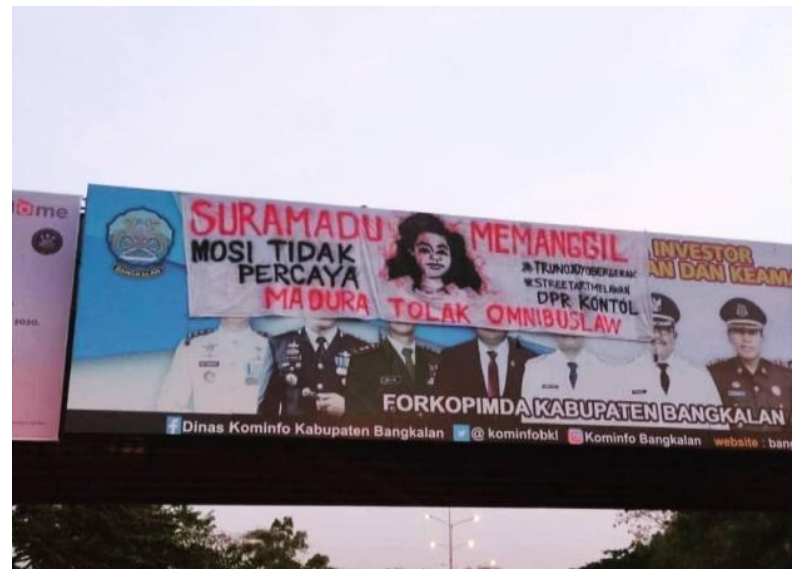

Figure 1. Rejection of the Omnibus Law in the form of a banner

Source: Taken directly from J1. Suramadu Madura side

Thursday, October 8, 2020, some banners with the words "no-confidence vote" began to be unfurled at some points in the Madura area. The banner is spread over a billboard before entering the Suramadu Bridge toll road. The banner that was spread was one of the calls for action from the Bangkala street art circles, the existence of the banner made Bangkalan activists moved and took action. The form of the demonstration carried out by Madurese students was carried out at the Surabaya House of Representatives which was held simultaneously with universities throughout Surabaya. This banner is a call for action and the beginning before the demonstrations carried out by the people of Bangkalan.

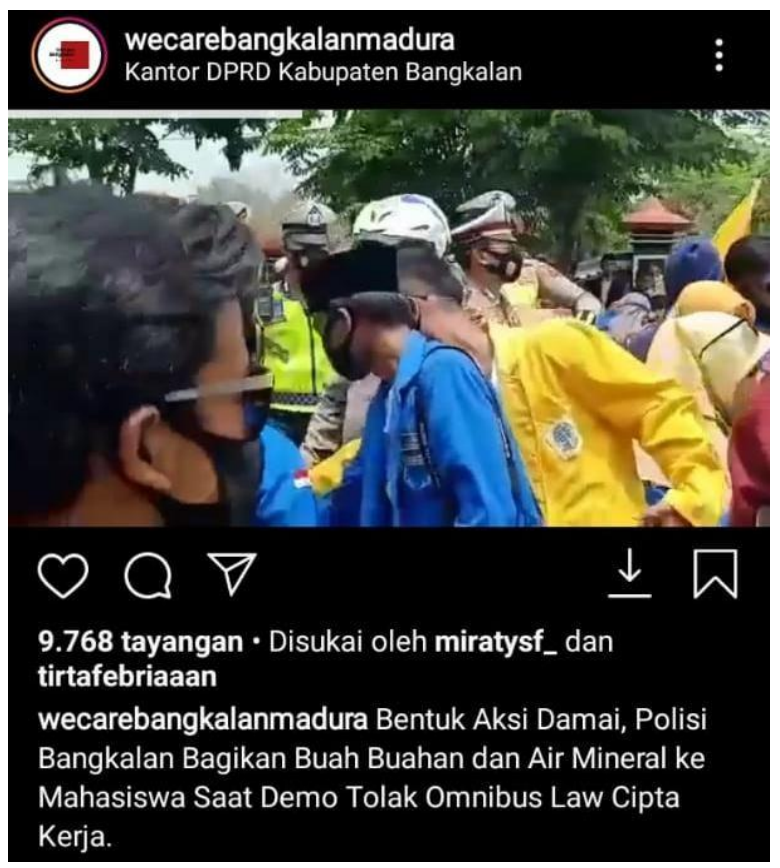

Figure 2. Peaceful Actions of Demonstrators and Police

Source: (Instagram 2020)

In Figure 2 it can be seen and explained that the demonstration was carried out peacefully by the Bangkalan students and police. The day after carrying out the demonstration in Surabaya, apparently Bangkalan students and activists continued to hold demonstrations at the Bangkalan DPRD on Friday, October 9, 2020, with an initial start from the Bangkalan Gelora Stadium (SGB). However, the intention to take a demonstration to the Bangkalan DPRD building was blocked by the Bangkalan police by bringing fruit and mineral water. As the caption stated above, the police distributed the fruits and mineral water to all demonstrators. The end of the demonstration process went peacefully between the demonstrators and the police. This is done by the police as a negotiation process between demonstrators and the police so that they do not take unwanted actions later. 


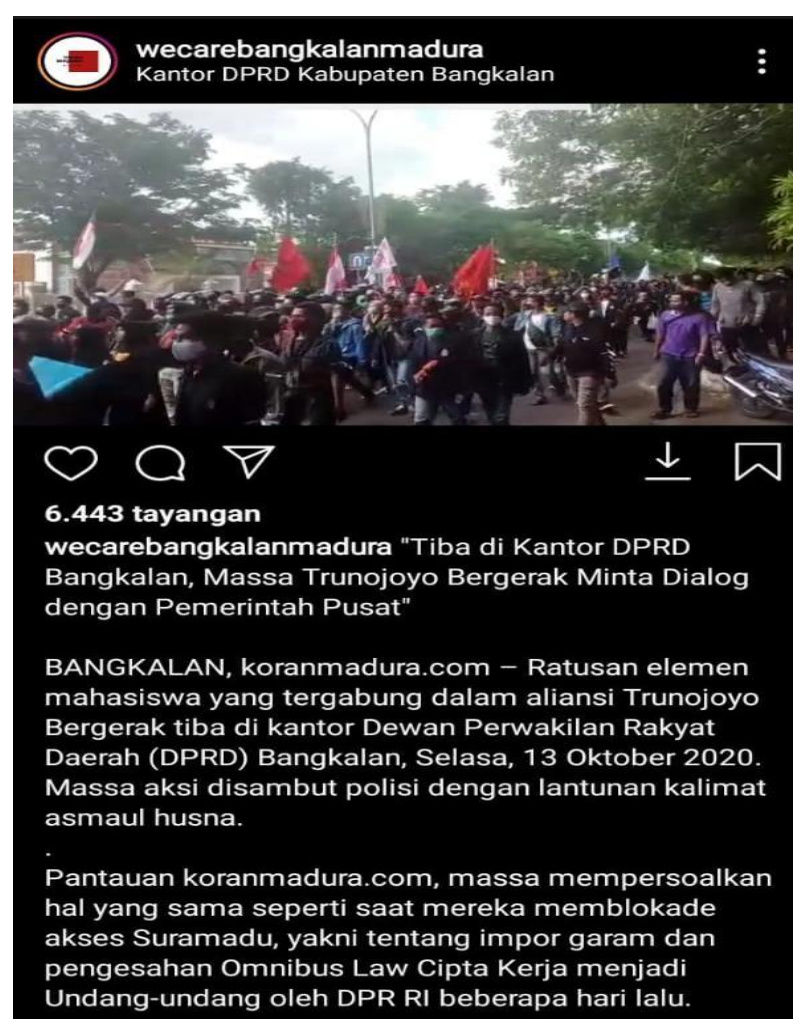

Figure 3. Actions asking for dialogue with the central government

Source: (Madura 2020)

Demonstrations did not stop for 3 days, but demonstrations in Bangkalan were still held on Tuesday, October 13, 2020. In Figure 3 it is explained that hundreds of student elements who are members of the Trunojoyo Bergerak alliance arrived at the Bangkalan DPRD office. In the picture above is a video uploaded by Instagram Wecarebangkalan which is always up to date regarding news that is viral. The news was also reported to newspapermadura.com which explained that the process of taking the action to go down the road was still the same questioning the same thing, namely the import of salt and the ratification of the Omnibus Law on Job Creation. According to Koranmadura.com's observation, they blocked Suramadu's access to the Bangkalan DPRD office. The purpose and objective of the Trunojoyo Bergerak alliance are to ask for a direct dialogue with the central government regarding the Omnibus Law Bill.

The mass of action was greeted by the police with the chanting of the phrase Asmaul Husna. The protesters did not want an answer from the Bangkalan DPRD regarding the attitude of importing salt and the Omnibus Law on Job Creation. However, they asked to be facilitated to meet with the central government, either in person or online.

"We don't need an answer from the Bangkalan DPRD, but we want to have a dialogue with the central government (via online/offline, ed)," shouted the orator of the action, Rossy.

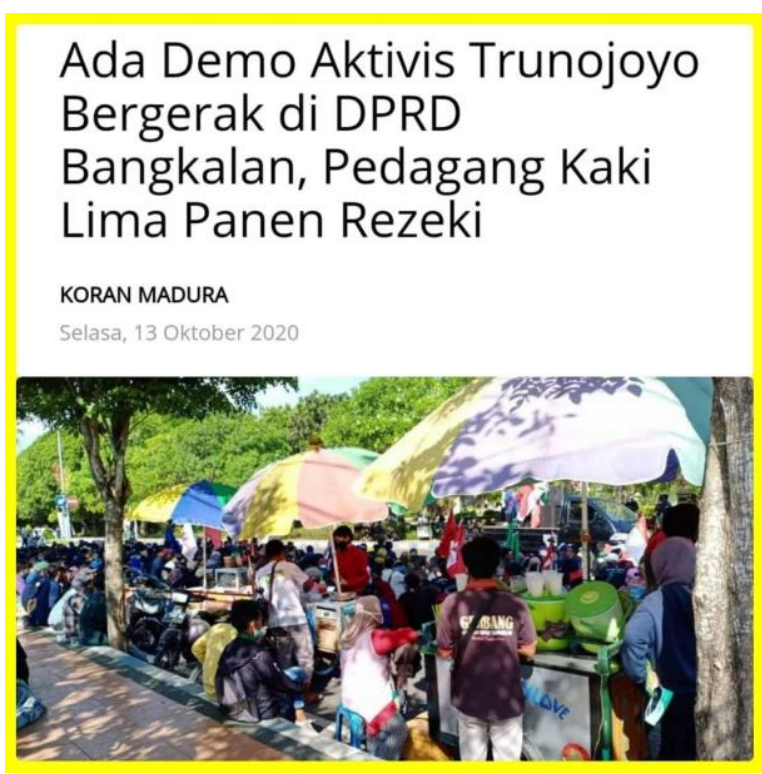

Figure 4. Demonstrations of Activists

Source: newspapermadura.com

The picture above explains that the demonstration by activists Trunojoyo Bergerak is profitable for street vendors. This news coincides with the news that has been described in the previous picture, namely picture 3 . The news on newspapermadura.com explains that the demonstration against the omnibus law on copyright work and salt imports held by hundreds of students belonging to the Trunojoyo alliance Moving in front of the Bangkalan DPRD office turned out to be profitable. for traders times five (PKL) ${ }^{[1]}$.

One of the ice sellers, who did not want to give his name, was happy because many of the goods he sold were bought by students who took part in the action against the Omnibus Law on Job Creation and the import of salt. "Alhamdulillah, the harvest, mas, many buy from students," said the father, while busy serving buyers, Tuesday, October 13, 2020. He admitted that when selling at the Population and Civil Registration Office (Dispendukcapil) it was very quiet. What's more, he said, Adminduk services have moved to the Public Service Mall (MPP).

When asked about the demonstration, his party hoped that the demonstrations carried out by students would proceed peacefully and well and the government could also understand the demands of the protesters ${ }^{[2]}$. 


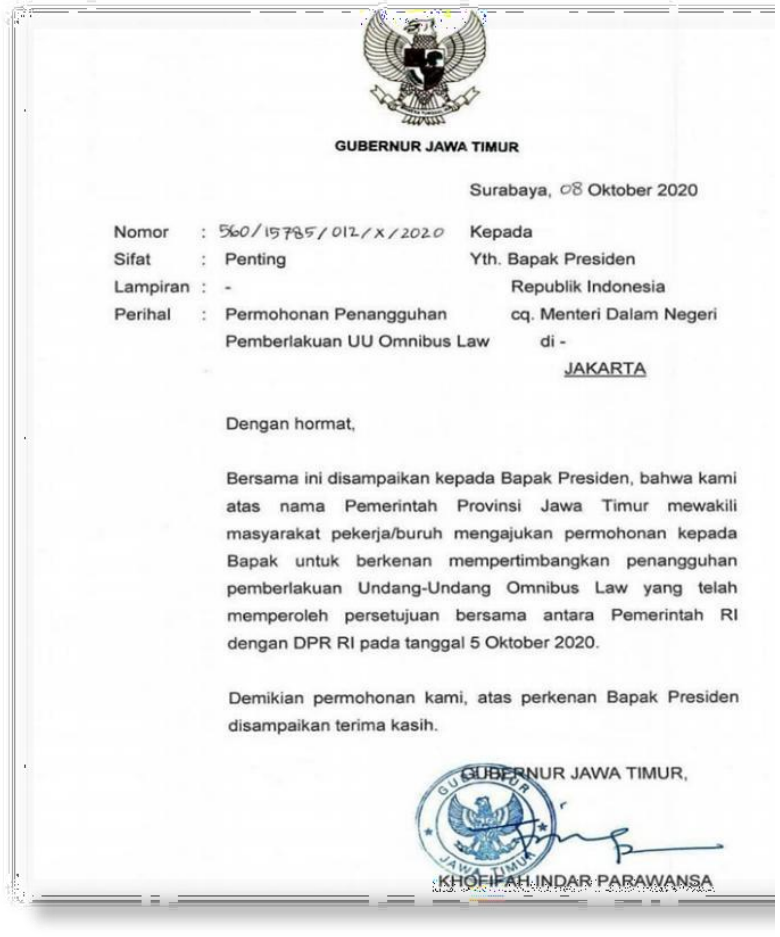

Figure 5. Dialog Results

Source: (Jatim 2020)

Figure 5 shows the letter from the Governor of East Java, Khofifah Indar Parawansa to President Joko Widodo regarding the request for a postponement of the enforcement of the Omnibus Law. From all forms of rebellion and demonstrations carried out by students and workers, the Governor of East Java issued a letter to Jakarta.

Demonstrations and resistance to the Bangkalan DPRD government were not as severe as in other areas. Even demonstrations in big cities such as Jakarta, Surabaya, Malang caused damage to public facilities. According to researchers in the sociology of law regarding government in Bnagkalan, Madura is less focused on and following the central government because most of the governments that hold Bangkalan, Madura are descendants of Kyai or religious leaders.

\section{CONCLUSION}

The ratification of the Omnibus Law is disturbing for the workers, it does not look at the place or region. Although the blood of Bangkalan, Madura is still considered quite behind, regarding the ratification of the Act, the public and students feel that investors will be harmed later. Madura Island is an island that is considered to be very detrimental to salt farmers in Madura.

The ratification of the Omnibus Law is indeed considered a universal sweeping law because many points are considered detrimental to many parties, such as workers. According to the public, the ratification of the Omnibus Law only benefits one party, namely the investor. The ratification of the Omnibus Law is very close to the word demonstration. The demonstration was carried out as a form of public rejection of the latest Bill (Draft Law) passed by the DPR RI.

The rejection was carried out in the form of demonstrations and sending letters from various regions to the central government (Jakarta) so that they could consider the ratification of the latest law which was considered detrimental to many parties. According to the sociology of law itself, this process of ratification is considered incompatible with Indonesian society. Maybe the government's intention to ratify the Omnibus Law is so that many investors invest and create new job opportunities for the community, but the arrival of investors to Indonesia will make people like cash cows who are forced to work for them.

\section{ACKNOWLEDGMENT}

Thank you to my lecturer for allowing me to take part in this prestigious event without being charged a penny. My next thanks go to friends who helped in the confusion while working. And I also don't forget to thank the people who have been involved in writing this research.

\section{REFERENCES}

[1] Aini, Nur. 2020. "Jokowi Explains the Omnibus Law of the Job Creation Law at the APEC Summit - Republika Online."

[2] Andry Novellino. nd "Rejecting the Omnibus Law, Indonesian Students Demo October 8th." CNN Indonesia.

[3] Annisa, Luluk, Arif Satria, and Rilus A Kinseng. 2009 3(1):11324. doi:10.22500/sodality.v3i1.5870.

[4] Anon. 2020. "The Meaning of Demonstration - Big Indonesian Dictionary (KBBI) Online."

[5] Lecturer of Sociology. 2020. "Lecturer of Sociology."

[6] Fuady, Munir. 2007. "Sociology of Contemporary Law."

[7] Hantoro, Novianto Murti. 2019. "Parliamentary Review." Parliamentary Review 1(1):61.

[8] Instagram, Admin. 2020. Forms of Peaceful Action.

[9] East Java, Info. 2020. Application for the Suspension of the Enforcement of the Omnibus Law.

[10] Jawahir, Rizal. 2020. "What is the Omnibus Law on Job Creation, Content, and Its Impact on Workers?" Compass.

[11] Lexy J, Moleong. 2010. Qualitative Research Methodology. Bandung: PT Rosdakarya. 
[12] Madura, Newspaper. 2020. Trunojoyo's Activities Demo Moves to the Bangkalan DPRD, Street Vendors for Harvesting Fortune.

[13] Persada, Syailendra. 2020. "5 Rules of the Omnibus Law on Job Creation which is considered to be detrimental to workers." Tempo. Co.

[14] Rijali, Ahmad. 2019. "Qualitative Data

Analysis." Alhadharah:
Da'wah Da'wah 17(33):81. 10.18592/alhadharah.v17i33.2374.

[15] Umanailo, M. Chairul Basrun. 2017. Sociology of Law. 